\title{
Salinites grossicostatum (Imlay, 1939) and S. finicostatum sp. nov. from the latest Tithonian (Late Jurassic) of northeastern Mexico
}

\author{
Patrick Zell1,*, Wolfgang Stinnesbeck ${ }^{1}$ \\ ${ }^{1}$ Institut für Geowissenschaften, Universität Heidelberg, Im Neuenheimer Feld 234, 69120 Heidelberg, Germany. \\ *PatrickZell@geow.uni-heidelberg.de
}

\begin{abstract}
Based on our taxonomic revision of the ammonite Salinites grossicostatum from the uppermost Tithonian of the La Caja Formation at Puerto Piñones, in the state of Coahuila, northeastern Mexico, we suggest that some specimens described from other Tithonian sites of Cuba and Mexico assigned to $S$. grossicostatum belong to a new species, here presented as S. finicostatum. Salinites grossicostatum and S. finicostatum sp. nov. are endemic to the ancient Gulf of Mexico and are restricted to outer continental shelf environments.
\end{abstract}

Keywords: Salinites grossicostatum, S. finicostatum, Tithonian, La Caja Formation, northeastern Mexico.

Resumen

Se describe el amonite Salinites grossicostatum del Tithoniano terminal, basándose en material procedente de la Formación La Caja y coleccionado en Puerto Piñones, estado de Coahuila, en el noreste de México. Nuestra revisión taxonómica indica que algunos especímenes descritos del Tithoniano de Cuba y México asignados a $\underline{S}$. grossicostatum, pertenecen a una nueva especie introducida

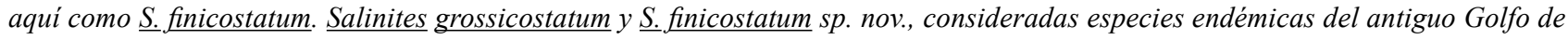
México; las cuales se restringen a la plataforma continental exterior.

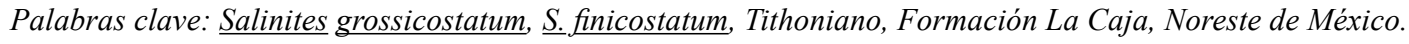

\section{Introduction}

Marine strata of the Upper Jurassic (KimmeridgianTithonian) to lowermost Cretaceous (Berriasian) La Caja Formation is widespread in northeastern and central Mexico and known for their abundant and diverse well-preserved ammonites (e.g., Burckhardt, 1906, 1930; Imlay, 1938; Peña-Muñoz, 1964; Verma and Westermann, 1973; LópezCaballero, 2009; Villaseñor et al., 2012, 2015). Here we document ammonites of the genus Salinites (Cantú-Chapa, 1968) from these lithostratigraphic units and discuss their stratigraphic and paleoecological importance. Salinites grossicostatum (Imlay, 1939) is restricted to the uppermost Tithonian Crassicollaria Zone (Adatte et al., 1994) and only occurs in outer shelf environments in the transitional zone between the continental platform and slope, as discussed below.

\subsection{Location}

The Salinites-bearing interval investigated here is located at Puerto Piñones (N25 02.719'/W101 ${ }^{\circ} 03.396^{\prime}$ ) in southern Coahuila state (Adatte et al., 1994; Zell et al., 2013, 2015; Zell and Stinnesbeck, 2015). A precise description of the locality and the section is provided by Zell and Stinnesbeck (2016, fig. 1). The Salinites-bearing layer consists of an approximately $0.3 \mathrm{~m}$ thick hemipelagic shaly limestone rich in ammonites. The assemblage is relatively diverse and is 
numerically dominated by Salinites grossicostatum (Imlay, 1939), but Himalayites, Kossmatia and Durangites are also present. The assemblage characterizes the "KossmatiaDurangites-Salinites beds" (cf. Cantú-Chapa, 2006); calpionellids from the layer are indicative of the uppermost Crassicollaria Zone (Adatte et al., 1994).

\subsection{Material and methods}

Our collection of Salinites grossicostatum consists of 169 specimens preserved three-dimensionally. They are well preserved, but suture lines are only visible in rare occasions. Specimens analyzed here were collected by WS during the late 1980s and early 1990s over a period of about eight years and are now deposited in the Colección de Paleontología de Coahuila of the Museo del Desierto in Saltillo, Coahuila, Mexico, under the collection numbers CPC-1214-1242, sample box CPC-1243 and CPC-14051413. The systematic description follows Arkell et al. (1957), Verma and Westermann (1973) and Wright et al. (1996). Abbreviations: D, diameter; Wh, whorl height; Ww, whorl width; U, umbilical diameter; U/D, umbilical ratio; $\mathrm{Ww} / \mathrm{Wh}$, whorl height to width ratio.

\section{Systematic Paleontology}

Phylum Mollusca Linnaeus, 1758

Class Cephalopoda Cuvier, 1797

Order Ammonoidea Zittel, 1884

Superfamily Haploceratacea Zittel, 1884

Family Haploceratida Zittel, 1884, sensu Ziegler, 1974

Genus Salinites Cantú-Chapa, 1968 1939

Type species. Hildoglochiceras grossicostatum Imlay,

Salinites grossicostatum (Imlay, 1939)

(Figure 1, Table 1)

Hildoglochiceras grossicostatum sp. nov. Imlay, 1939, p. 27, pl. 2, figs. 5-11, pl. 3, figs. 1-7, 9-11; Imlay, 1942, p. 1444, pl. 2, figs. 3-5; Carreño et al., 1989, p. 219, fig. 77e.

Haploceras cubensis sp. nov. Judoley and FurrazolaBermúdez, 1968, p. 55, pl. 3, figs. 2-3.

Salinites grossicostatum (Imlay, 1939); Cantú-Chapa, 1976, pl. 1, figs. 1 a-d, f, g, 2 g, 7 a, 8 e, f, pl. 2, fig. 4a; non Cantú-Chapa, 1968, p. 21, pl. 4, figs. 1, 4, 7, 9, pl. 5, figs. 3, 8, 10; ? Imlay and Herman, 1984, p. 160, pl. 1, figs. 9-11; Zell and Stinnesbeck, 2016, p. 4, fig. 3.

Hildoglochiceras (Salinites) grossicostatum (Imlay, 1939); Myczyński, 1989, p. 86, pl. 2, figs. 10-13, pl. 3, figs. 1-3, 5, 9, 12, pl. 4, figs. 10b, 11a; Myczyński and Pszczółkowski, 1990, pl. 1, fig. 3; non Myczyński, 1989, p. 86 , pl. 1, fig. 4 , pl. 3 , fig. 8 , pl. 4 , figs. 1,2 , 11 b.

\subsection{Description}

A detailed description of the ontogenetic development and interior shell parameters of Salinites grossicostatum is provided by Zell and Stinnesbeck (2016). The authors also document sexual dimorphism in S. grossicostatum based on the presence of micro- and macroconchs with diverging trends in septal spacing, especially during the post-embryonic stage. Dimensions of selected specimens are presented in Table 1.

\subsection{Remarks}

The genus Hildoglochiceras is characterized by an evolute compressed shell with a deep median furrow, an apophysis, and strong rursiradiate ventrolateral ribs (see Wright, in Arkell et al., 1957). This diagnosis is only consistent with a single species (Hildoglochiceras diaboli Imlay, 1939, p. 25, pl. 6, figs. 8-10) of a total of eight taxa from Mexico originally assigned to Hildoglochiceras by Imlay (1939). These Mexican specimens were revised and separated from Hildoglochiceras by Cantú-Chapa (1968, p. 19), based on their high degree of involution and the presence of a whorl depression at the dorso- to middle-lateral region of the flank. The author established a new genus, Salinites, for these Mexican representatives and included Hildoglochiceras grossicostatum Imlay (1939, p. 27, pl. 2, figs. 5-11, pl. 3, figs. 1-7, 9-11) from the "Durangites beds" of the La Casita Formation at Sierra de Parras, Coahuila. Hildoglochiceras propinquum Waagen (1873-1875, p. 45, pl. 11, figs. 4a, b) and $H$. dieneri Uhlig (1903-1910, p. 18, pl. 7, figs. 8a, b) from the Jurassic of India were considered to be similar to Salinites grossicostatum (e.g., Imlay, 1939), but are less involute and their ribs are less pronounced. Paraglochiceras Collignon, 1959 has a larger whorl width and no lateral furrow is present, while Glochiceras Hyatt, 1900 is more involute and almost smooth.

\subsection{Occurrence}

Salinites grossicostatum was first described by Imlay (1939) from the upper Tithonian Durangites beds in the Sierra de Parras and Sierra de Jimulco, Coahuila, Mexico. The investigated limestone containing S. grossicostatum at Puerto Piñones was assigned by Adatte et al. (1994) to the uppermost Tithonian "Durangites beds" and to the upper Crassicollaria Zone, and is stratigraphically located only a few tens of millimeters below the Jurassic-Cretaceous boundary identified on the basis of calpionellid occurrences (Adatte et al., 1994) and the recent identification of the belemnite Rhaphibelus aciculiformis Zell et al. (2013). At Puerto Piñones, Salinites grossicostatum is associated with Proniceras, Himalayites and Durangites (and related forms).

Outside the state of Coahuila, $S$. aff. grossicostatum was documented from a bore hole (Paras No. 1) in 

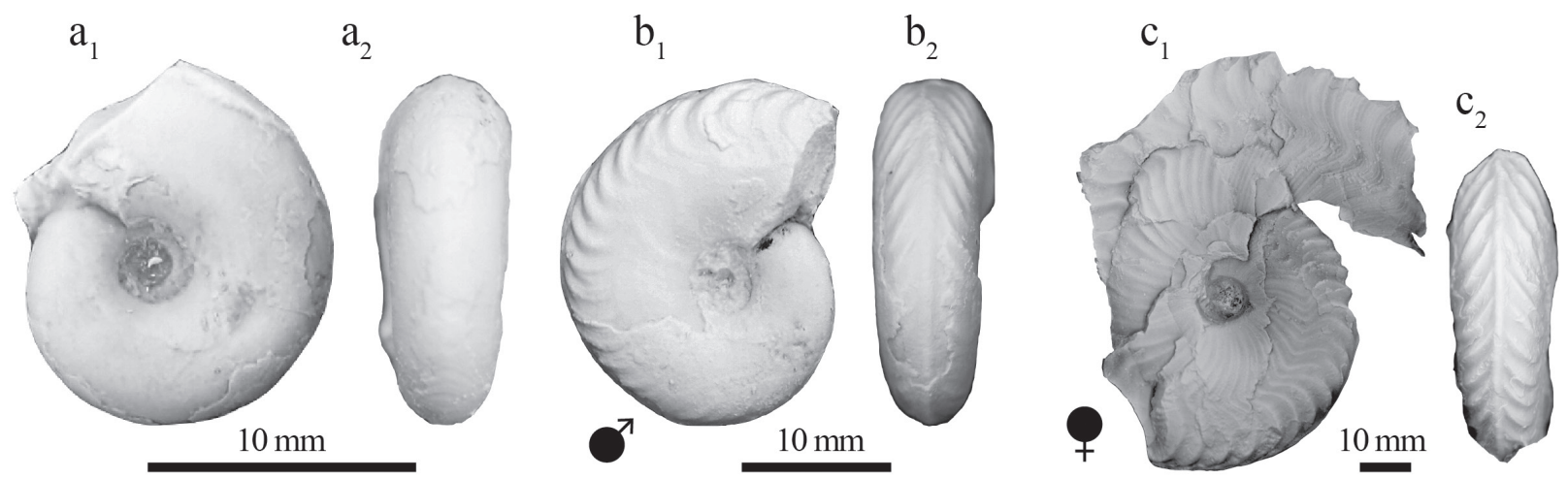

Figure 1. Representative specimens of Salinites grossicostatum (Imlay, 1939) from the uppermost Tithonian at Puerto Piñones, Coahuila, Mexico, representing an ontogenetic series from juvenile (a) to mature (c); (a) CPC-1405; (b) CPC-1408, microconch; (c) CPC-1413, macroconch. The specimens were previously illustrated in Zell and Stinnesbeck (2016, fig. 3).

Table 1. Dimensions of selected specimens (in $\mathrm{mm}$ ).

\begin{tabular}{|c|c|c|c|c|c|c|}
\hline Sample & D & Wh & $\mathbf{W w}$ & $\mathbf{U}$ & U/D & $\mathbf{W w} / \mathbf{W h}$ \\
\hline CPC-1221 & 53 & 25 & - & 9 & 0.17 & - \\
\hline CPC-1222 & 40 & 19.8 & 14 & 7.1 & 0.18 & 0.71 \\
\hline CPC-1223 & 42 & 21.5 & 14.2 & 7.4 & 0.18 & 0.66 \\
\hline CPC-1224 & 38 & 20.2 & 12.8 & 6.5 & 0.27 & 0.64 \\
\hline CPC-1225 & 34.5 & 17.8 & 9.8 & 5 & 0.15 & 0.55 \\
\hline CPC-1226 & 35 & 19 & 12.7 & 5.5 & 0.16 & 0.67 \\
\hline CPC-1227 & 28 & 14.5 & 7.6 & 3.4 & 0.12 & 0.52 \\
\hline CPC-1228 & 24.5 & 12.6 & 8 & 5 & 0.2 & 0.54 \\
\hline СРC-1229 & 34.5 & 17.4 & 10.5 & 5.5 & 0.16 & 0.6 \\
\hline CPC-1230 & 45.6 & 25 & - & 6.8 & 0.15 & - \\
\hline CPC-1231 & 8.1 & 4 & 2.9 & 1.8 & 0.22 & 0.73 \\
\hline CPC-1232 & 6.9 & 4.5 & 3.4 & 2 & 0.21 & 0.76 \\
\hline CPC-1233 & 10.3 & 5.2 & 3.8 & 2.1 & 0.2 & 0.73 \\
\hline CPC-1234 & 12 & 6.3 & 4.3 & 2.4 & 0.2 & 0.68 \\
\hline CPC-1235 & 12.5 & 6.8 & 4.5 & 2.4 & 0.19 & 0.66 \\
\hline CPC-1236 & 16 & 8 & 5 & 3 & 0.19 & 0.63 \\
\hline CPC-1237 & 17 & 9 & 5.5 & 3 & 0.18 & 0.61 \\
\hline CPC-1238 & 18.5 & 9 & 6 & 3.8 & 0.21 & 0.66 \\
\hline CPC-1239 & 19 & 10.2 & 6.5 & 3 & 0.16 & 0.64 \\
\hline CPC-1240 & 21.2 & 11.6 & 6.8 & 3.2 & 0.15 & 0.58 \\
\hline CPC-1241 & 23.1 & 12.6 & 6.5 & 3.5 & 0.15 & 0.52 \\
\hline CPC-1242 & 24 & 12.5 & 7.2 & 3.7 & 0.15 & 0.58 \\
\hline CPC-1405 & 12 & 6.1 & 3.9 & 2.8 & 0.23 & 0.64 \\
\hline CPC-1408 & 24.1 & 11 & 7.9 & 4.3 & 0.18 & 0.69 \\
\hline CPC-1413 & - & - & 18.9 & 13.8 & - & - \\
\hline
\end{tabular}


northern Nuevo León (Cantú-Chapa, 1968), associated with Substeueroceras ?imlayi (Cantú-Chapa, 1963) and Paradontoceras. Cantú-Chapa (1976) also identified several specimens of $S$. grossicostatum from the upper Tithonian portion of the La Pimienta Formation in bore hole Bejuco No. $6,70 \mathrm{~km}$ south of Tampico, in Tamaulipas.

In these sections of the Gulf coast of northeastern Mexico (Figure 2), S. grossicostatum occurs in outer shelf environments at the transition between the continental shelf and slope (e.g., Adatte et al., 1994). Interestingly, in other correlative sections from the region the taxon is characteristically absent in the Tithonian-Berriasian transition interval; e.g., at Sierra de Chorreras, Chihuahua (Cantú-Chapa, 1976), San Pedro del Gallo, Durango (Burckhardt, 1912; Contreras et al., 1988), Sierra de Catorce, San Luis Potosí (Verma and Westermann, 1973), Tamán, San Luis Potosí (Cantú-Chapa, 1984) and Mazatepec, Puebla (Cantú-Chapa, 1967; Stinnesbeck et al., 1993). These latter sections are either considered to represent environments more shallow than the deposits at the localities with Salinites grossicostatum (e.g., Sierra de Chorreras, Chihuahua state, Sierra de Catorce, San Luis Potosí state), or they represent a deeper marine environment on the slope or within the basin (e.g., San Pedro del Gallo, Durango state, Tamán, San Luis
Potosí state, and Mazatepec, Puebla state).

Outside Mexico, Salinites grossicostatum was reported from the Tithonian Bossier Formation at Sabine Parish, Louisiana, USA (Imlay and Herman, 1984, p. 160, pl. 1, figs. 9-11) and from the upper Tithonian of Sierra de Los Órganos in western Cuba (Imlay, 1942, p. 1444, pl. 2, figs. 3-5; Judoley and Furrazola-Bermúdez, 1968, p. 19; Myczyński, 1989; Myczyński and Pszczółkowski, 1990). The records of the species in Cuba and the southern USA represent depositional environments considered to be similar to the environments containing Mexican occurrences of S. grossicostatum (see Fig. 2, localities 6 and 7).

At Puerto Piñones, $S$. grossicostatum is restricted to the latest Tithonian (Adatte et al., 1994; Zell and Stinnesbeck, 2016). This is consistent with the age assigned to the specimens at other sites in Mexico (Imlay, 1939; CantúChapa, 1976). According to Myczyński and Pszczółkowski (1994) and Myczyński (1999), Cuban Salinites are also restricted to the latest Tithonian based on the presence of calpionellids preserved in the upper part of the La Zarza Member of the Artemisa Formation, above the "VinalesitesProtancyloceras" assemblage. Myczyński (1989) also identified Salinites in the El Americano Member of the Guasasa Formation. Cobiella-Reguera and Olóriz (2009)

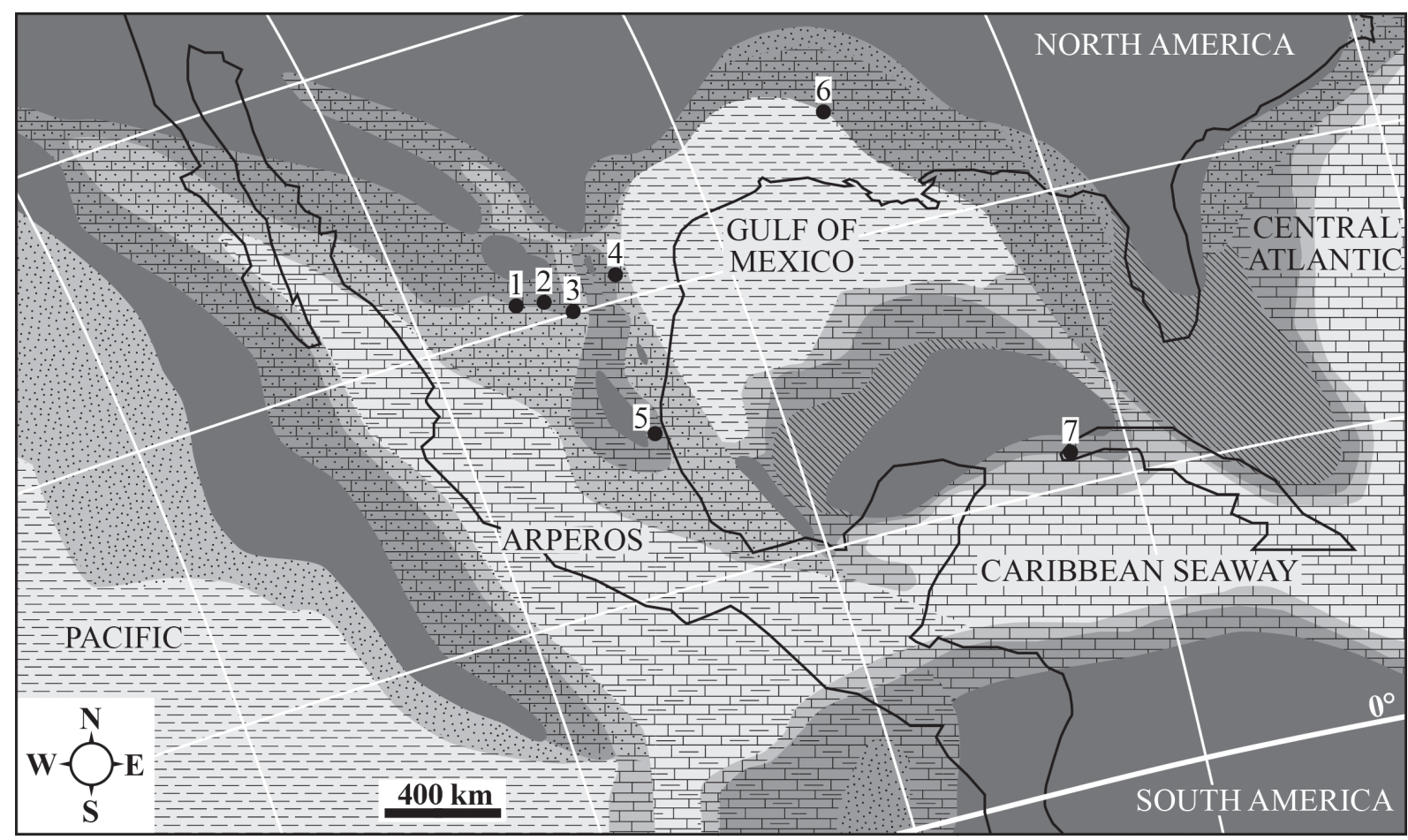

$\square$ exposed land

$\square$ shallow marine

$\square$ hemipelagic

$\square$ pelagic

sand, silt Eevaporite

limestone alternance of limestone, sand, silt and clay

Figure 2. Tithonian paleogeographic map of the Gulf of Mexico and adjacent realms including latest Tithonian occurrences of Salinites grossicostatum (see numbers). The distribution of $S$. grossicostatum is restricted to shallow marine, outer shelf environments. (1) Sierra de Jimulco; (2) Sierra de Parras; (3) Puerto Piñones; (4) bore hole Paras No. 1; (5) bore hole Bejuco No. 6; (6) Sabine Parish; (7) Sierra de Los Órganos. Map simplified and redrawn after Wilhem (2014), with additional information from Goldhammer and Johnson (2001); see text for locality information. 
assigned Cuban Salinites-bearing beds from the El Americano Member to the latest Tithonian-early middle Berriasian (upper Crassicollaria and/or Calpionella zones). Nevertheless, the precise age of the sediments is debated (see Pszczółkowski, 2013).

\section{Salinites finicostatum sp. nov.}

(Figure 3)

Salinites grossicostatum (Imlay, 1939); Cantú-Chapa, 1968, p. 21, pl. 4, figs. 1, 4, 7, 9, pl. 5, figs. 3, 8, 10.

Hildoglochiceras (Salinites) grossicostatum (Imlay, 1939); Myczyński, 1989, p. 86, pl. 1, fig. 4, pl. 3, fig. 8, pl. 4, figs. 1, 2, 11b.

\subsection{Material}

One three-dimensionally preserved specimen (CPC1404) from a Corg.-rich mudstone of the uppermost $\mathrm{La}$ Caja Formation at Cañón de Huizachal, Tamaulipas state (for locality see Montellano et al., 2008, p. 1131, fig. 1), associated with an imprint of an ammonite assigned to Suarites. Accompanying calpionellids are rare but indicate a latest Tithonian or earliest Berriasian age. Suture-lines are not visible.

\subsection{Etymology}

The species name "finicostatum" is Latin for "fineribbed".

\subsection{Diagnosis}

A Salinites with finer and less regular ribs than those of S. grossicostatum (Imlay, 1939). The taxon is also distinguished from this latter species by a slightly wider umbilicus, higher whorl widths and a stronger serrated keel.

\subsection{Description}

Medium sized $(\mathrm{D}=29.5 \mathrm{~mm})$, involute (U/D = 0.2), discoidal with largest whorl width closely below the middle of the flank $(\mathrm{Wh}=15 \mathrm{~mm} ; \mathrm{Ww}=10.3 \mathrm{~mm} ; \mathrm{Ww} / \mathrm{Wh}=$ $0.69)$. The umbilicus is narrow $(\mathrm{U}=6.0 \mathrm{~mm})$ and shallow; the umbilical wall is vertical. The flanks are convex, the venter rounded with a serrated keel. Fine, prorsiradiate ribs of equal strength are present between the umbilical ridge and mid-flank. Fine ventrolateral ribs of irregular strengths and spacing are present; they are simple but some bifurcate closely above mid-flank. Here they are rursiradiate but ventrolaterally become prorsiradiate.

\subsection{Remarks}

Imlay's type material of Hildoglochiceras grossicostatum (Imlay, 1939, pl. 3, figs. 3, 4) consists of juveniles $\left(D_{\max }=\right.$ $24.5 \mathrm{~mm}$ ); however, adult material of Cantú-Chapa (1968), as well as specimens described by Myczyński (1989) from the Tithonian of Cuba, differ from Imlay's type material of Hildoglochiceras grossicostatum and from our material from Puerto Piñones by finer ribs of irregular expression and spaced at smaller distances. These differences are here considered to be significant and permit definition of a new species of Salinites, S. finicostatum. Haploceras cubensis Judoley and Furrazola-Bermúdez (1968, p. 55, pl. 3, fig. 1) from the upper Kimmeridgian to lower Tithonian Artemisa Formation of western Cuba is similar in ribbing, but differs from S. finicostatum by slightly less involute coiling, a pronounced lateral furrow during early ontogenetic stages and by a smaller whorl width.

\subsection{Occurrence}

Salinites finicostatum is here reported from the upper
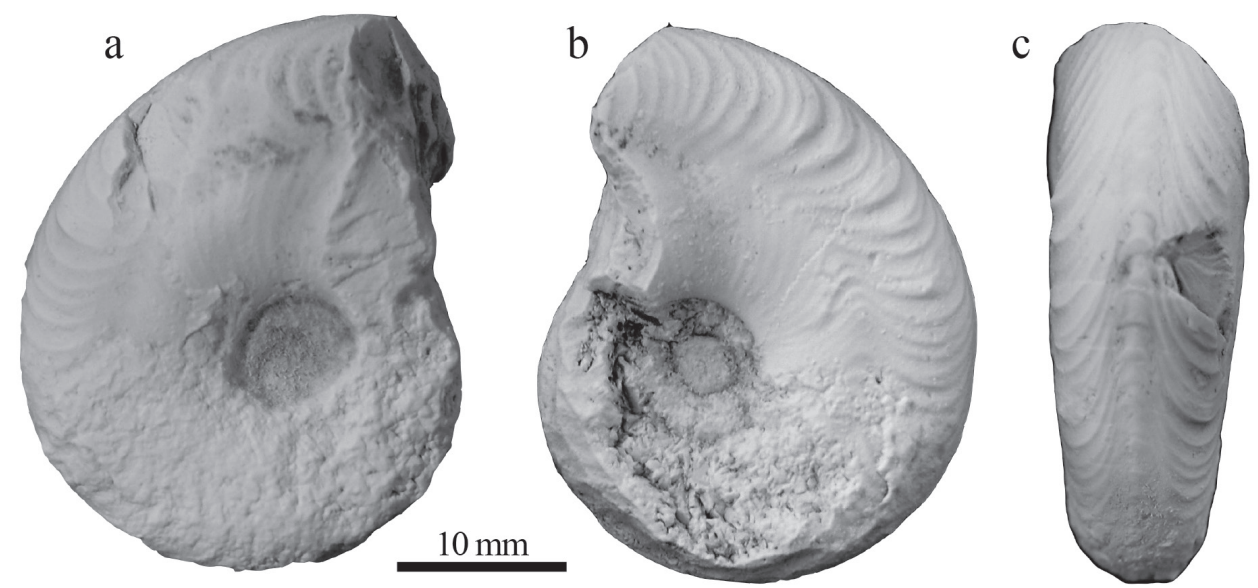

Figure 3. Salinites finicostatum sp. nov. (CPC-1404) from the uppermost La Caja Formation at Cañón de Huizachal, Tamaulipas. (a) left side view; (b) right side view; (c) ventral view. 
Tithonian-lower Berriasian of Huizachal Canyon in Tamaulipas as described here, and the upper Tithonian at Rancho Las Juanas at Galeana, Nuevo León, associated with Proniceras (P.) subpronum Burckhardt (1919-1921) and Durangites spp. (Cantú-Chapa, 1968). The species is also present in the upper Tithonian of Cuba (Myczyński, 1989, p. 86 , pl. 1, fig. 4, pl. 3, fig. 8, pl. 4, figs. 1, 2, 11b) and is there associated with Salinites grossicostatum (Myczyński, 1989 , p. 86, pl. 2, figs. 10-13, pl. 3, figs. 1-3, 5, 9, 12, pl. 4 , figs. 10b, 11a).

\section{Conclusions}

Salinites grossicostatum (Imlay, 1939) is restricted to the Crassicollaria Zone (Adatte et al., 1994) of the uppermost Tithonian "Kossmatia-Durangites-Salinites Beds" (cf. Cantú-Chapa, 2006). The species, known from Coahuila and Nuevo León in Mexico, western Cuba, and the southern US, only occurs in outer shelf environments in the transitional zone between the inner continental shelf and slope. A second, closely related taxon, Salinites finicostatum sp. nov., occurs in coeval strata in the Mexican states of Tamaulipas and Nuevo León (Cantú-Chapa, 1968) and is also present in Cuba (Myczyński, 1989), but its ecological preferences are unclear. Salinites is thus endemic to the ancient Gulf of Mexico.

\section{Acknowledgements}

Financial support for this research was provided by the Deutsche Forschungsgemeinschaft (DFG STI 12817). The authors acknowledge Seija Beckmann for fossil photography and Timothy Lawton and one anonymous reviewer for their careful corrections and comments.

\section{References}

Adatte, T., Stinnesbeck, W., Hubberten, H., Remane, J., 1994, The JurassicCretaceous boundary in Northeastern Mexico. Confrontation and correlations by microfacies, clay mineral mineralogy, calpionellids and ammonites: 3ème Symposium International de Stratigraphie du Jurassique,Geobios, Mémoire Spécial, 17, 37-56.

Arkell, W.J., Furnish, W.M., Kummel, B., Miller, A.K., Moore, R.C., Schindewolf, O.H., Sylvester-Bradley, P.C., Wright, C.W., 1957, Cephalopoda, Ammonoidea, Mollusca 4, Part L, in Moore, R.C. (ed.), Treatise on Invertebrate Paleontology: Geological Society of America and University of Kansas Press, L1-L472.

Burckhardt, C., 1906, La faune Jurassique de Mazapil avec un appendice sur les fossiles de Crétacique inférieur: Boletín del Instituto Geológico de México, 23, 1-217.

Burckhardt, C., 1912, Faunes Jurassiques et Cretaciques de San Pedro del Gallo: Boletín del Instituto Geológico de México, 29, 1-264.

Burckhardt, C., 1919-1921, Faunas Jurasicas de Symon (Zacatecas) y faunas Cretacicas de Zumpango Del Rio (Guerrero): Boletín del Instituto Geológico de México, 33, 1-136.

Burckhardt, C., 1930, Etude synthétique sur le Mésozoïque mexicain: Mémoires de la Société Paléontologiques Suisse, IL-L, 1-280.
Cantú-Chapa, A., 1963, Étude biostratigraphique des ammonites du centre et de l'est du Mexique: Mémoires de la Société Géologique de France, nouvelle série, mémoire, 99, 1-99.

Cantú-Chapa, A., 1967, El límite Jurásico-Cretácico en Mazatepec, Puebla. Estratigrafía del Jurásico de Mazatepec, Puebla (México): Instituto Mexicano del Petróleo, Sección Geología, Monografía, 1, 3-24.

Cantú-Chapa, A., 1968, Sobre una asociación Proniceras-Durangites"Hildoglochiceras" del Noreste de México: Instituto Mexicano del Petróleo, 2, 19-26.

Cantú-Chapa, A., 1976, El contacto Jurásico-Cretácico, le estratigrafía del Neocomiano, el Hiato Hauteriviano Superior-Eoceno Inferior y las amonitas del Pozo Bejuco 6 (centro-Este de México): Boletín de la Sociedad Geológica Mexicana, 37(2), 60-83.

Cantú-Chapa, A., 1984, El Jurásico Superior de Tamán, San Luis Potosí, este de México, in Perrilliat, M.C. (ed.), Memoria Tercer Congreso Latinoamericano de Paleontología, México D.F., Universidad Nacional Autónoma de México, Instituto de Geología, 207-215.

Cantú-Chapa, A., 2006, New Upper Tithonian (Jurassic) ammonites from Chinameca Formation in southern Veracruz, eastern Mexico: Journal of Paleontology, 80(2), 294-308.

Carreño, A.L., Perrilliat, M. del C., González-Arreola, C., Applegate, S.P., Carranza-Castaneda, O., Martínez-Hernández, E., 1989, Fósiles Tipo Mexicanos: Publicación Especial del Centenario del Instituto de Geología, UNAM, 1-531.

Cobiella-Reguera, J.L., Olóriz, F., 2009, Oxfordian-Berriasian stratigraphy of the North American paleomargin in western Cuba: Constraints for the geological history of the proto-Caribbean and the early Gulf of Mexico, in Bartolini, C., Roman Ramos, J.R. (eds.), Petroleum Systems in the southern Gulf of Mexico: American Association of Petroleum Geologists Memoir, 90, 421-451.

Collignon, M., 1959, Atlas des fossiles caractéristiques de Madagascar. Fascicule V (Kimméridgie): Service Géologique Tananarive, 1-96.

Contreras, M.B., Martínez, A., Gómez, M.E., 1988, Bioestratigrafía y sedimentología del Jurásico Superior en San Pedro de Gallo, Durango, Mexico: Revista del Instituto Mexicano del Petróleo, 20(3), 5-49.

Cuvier, G., 1797, Second Mémoire sur l'organisation et les rapports des animaux à sang blanc, dans lequel on traite de la structure des Mollusques et de leur division en ordre, lu à la société d'Histoire Naturelle de Paris, le 11 prairial an troisième [30 May 1795]: Magazin Encyclopédique, ou Journal des Sciences, des Lettres et des Arts, 1795 [1. année] 2, 433-449.

Goldhammer, R.Z., Johnson, C.A., 2001, Middle Jurassic-Upper Cretaceous paleogeographic evolution and sequence-stratigraphic framework of the northwest Gulf of Mexico rim, in Bartolini, C., Buffler, R.T., Cantú-Chapa, A. (eds.), The western Gulf of Mexico Basin: Tectonics, sedimentary basins, and petroleum systems: American Association of Petroleum Geologists Memoir, 75, 45-81.

Hyatt, A., 1900, Cephalopoda, in Zittel, K.A. (ed.), Textbook of Paleontology: 1st English Edition: London, Macmillan Publishers, 502-592.

Imlay, R.W., 1938, Studies on the Mexican Geosyncline: Bulletin of the Geological Society of America, 49, 1651-1694.

Imlay, R.W., 1939, Upper Jurassic ammonites from Mexico: Bulletin of the Geological Society of America, 50, 1-78.

Imlay, R.W., 1942, Late Jurassic fossils from Cuba and their economic significance: Bulletin of the Geological Society of America, 53, 1417-1478.

Imlay, R.W., Herman, G., 1984, Upper Jurassic ammonites from the subsurface of Texas, Louisiana and Mississippi, in Ventress, W.P.S., Bebout, D.G., Perkins, B.F., Moore, C.H. (eds.), The Jurassic of the Gulf Rim: Gulf Coast Section, Society for Sedimentary Geology, Third Annual Research Conference Proceedings, 149-170.

Judoley, C.M., Furrazola-Bermúdez, G., 1968, Estratigrafía y fauna del Jurásico de Cuba: Instituto Cubano de Recursos Minerales, La Habana, Publicación Especial, 1-126.

Linnaeus, C., 1758, Systema Naturae per Regna Tria Naturae, Secundum Classes, Ordines, Genera, Species, cum Characteribus, Differentiis, Synonymis, Locis: Tomus 1, 10th edition, L. Salvii, Stockholm, 
1-824.

López-Caballero, I., 2009, Bioestratigrafía y Tafonomía de la sección estratigráfica Puerto Piñones (Jurásico Superior) del área de Saltillo, Coahuila, México: Ciudad de México, D.F., Mexico, Instituto de Geología, Universidad Nacional Autónoma de México, Master degree Thesis.

Montellano, M., Hopson, J.A., Clark, J.M., 2008, Late Early Jurassic Mammaliforms from Huizachal Canyon, Tamaulipas, México: Journal of Vertebrate Paleontology, 28(4), 1130-1143.

Myczyński, R., 1989, Ammonite biostratigraphy of the Tithonian of Western Cuba: Annales Societatis Geologorum Poloniae, 59, 43-125.

Myczyński, R., 1999, Some ammonite genera from the Tithonian of western Cuba and their palaeobiogeographic importance: Studia Geologica Polonica, 114, 91-112.

Myczyński, R., Pszczółkowski, A., 1990, Tithonian stratigraphy in the Sierra de los Organos, Western Cuba: correlation of the ammonite and microfossil zones, in Pallini, G., Cecca, F., Cresta, S., Sanantonio, M. (eds.), Fosilli, Evoluzione, Ambiente: Atti delsecondo convegno internazionale, Pergola 25-30 ottobre 1987, 405-415.

Myczyński, R., Pszczółkowski, A., 1994, Tithonian stratigraphy and microfacies in the Sierra del Rosario, western Cuba: Studia Geologica Polonica, 105, 7-38.

Peña-Muñoz, M.J., 1964, Amonitas del Jurasico superior y del Cretácico inferior del extremo oriental del Estado de Durango, México: Paleontología Mexicana, 20, 1-33.

Pszczółkowski, A., 2013, Comment on "Calpionellid distribution and microfacies across the Jurassic/Cretaceous boundary in western Cuba (Sierra de los Órganos)": Geologica Carpathica, 64(6), 497-498.

Stinnesbeck, W., Adatte, T., Remane, J., 1993, Mazatepec (Estado de Puebla, Mexico) - Reevaluación de su valor como estratotipo del limite Jurásico-Cretácico: Revista Española de Micropaleontología, 25(2), 63-79.

Uhlig, V., 1903-1910, The fauna of the Spiti Shales (Cephalopoda): Palaeontographica Indica, Series 15, Volume 4, 1-132.

Verma, H.M., Westermann, G.E.G., 1973, The Tithonian (Jurassic) ammonite fauna and stratigraphy of Sierra de Catorce, San Luis Potosí, Mexico: Bulletin of the American Paleontology, 63(277), 107-320.

Villaseñor, A.B., Olóriz, F., López Palomino, I., López-Caballero, I., 2012, Updated ammonite biostratigraphy from Upper Jurassic deposits in Mexico: Revue de Paléobiologie, Genève, Vol. spec. 11, 249-267.

Villaseñor, A.B., Moliner, L., Olóriz, F., 2015, Schneidia zacatense sp. nov. - First population level study of Ataxioceratinae from the Lower Kimmeridgian in northern Mexico - Biostratigraphic and palaeobiogeographic significance: Journal of South American Earth Sciences, 63, 217-243.

Waagen, W., 1873-1875, Jurassic Fauna of Kutch: Palaeontologia Indica, $15,133-395$.

Wilhem, C., 2014, Maps of the Callovian and Tithonian Paleogeography of the Caribbean, Atlantic, and Tethyan Realms: Facies and Environments: Geological Society of America Digital Map and Chart Series 17, sheet 2 (Tithonian paleogeography), doi:10.1130/2014. $\mathrm{DMCH} 017 . \mathrm{S} 2$

Wright, C.W., Callomon, J.H., Howarth, M.K., 1996, Cretaceous Ammonoidea (revised), in Kaesler, R. (ed.), Treatise of Invertebrate Paleontology Part L, Mollusca 4, 20: United States of America, Kansas, Geological Society of America/The University of Kansas Press, Boulder and Lawrence, 1-362.

Zell, P., Beckmann, S., Stinnesbeck, W., 2013, Late Jurassic-earliest Cretaceous belemnites (Cephalopoda : Coleoidea) from northeastern Mexico and their palaeobiogeographic implications: Neues Jahrbuch für Geologie und Paläontologie, Abhandlung 270/3, 325-341.

Zell, P., Crame, J.A., Stinnesbeck, W., Beckmann, S., 2015, The bivalve Anopaea (Inoceramidae) from the Upper Jurassic-lowermost Cretaceous of Mexico: Journal of South American Earth Sciences, 60, 92-103.

Zell, P., Stinnesbeck, W., 2015, Kimmeridgian (Late Jurassic) cold-water idoceratids (Ammonoidea) from southern Coahuila, northeastern Mexico, associated with Boreal bivalves and belemnites: Revista Mexicana de Ciencias Geológicas, 32(1), 11-20.

Zell, P., Stinnesbeck, W., 2016, Paleobiology of the latest Tithonian (Late Jurassic) ammonite Salinites grossicostatum inferred from internal and external shell parameters: PLoS ONE, 11(1), doi:10.1371/ journal.pone. 0145865

Ziegler, B., 1974, Über Dimorphismus und Verwandtschaftsbeziehungen bei Oppelien des oberen Juras (Ammonoidea, Haplocerataceae): Stuttgart Beitr Naturk. B(11): 1-41.

Zittel, K.A. von, 1884, Cephalopoden, in Zittel, K.A. von (ed.), Handbuch der Palaeontologie, Band 1, Abteilung 2, Lieferung 3: Germany, Oldenbourg, Munich and Leipzig, 329-522.

Manuscript received: December 14, 2015

Corrected manuscript received: January 6, 2016

Manuscript accepted: January 18, 2016 